\title{
West Nile Virus as a Cause of Death Among Endangered Eastern Loggerhead Shrikes, Lanius ludovicianus migrans, in West St. Paul, Manitoba
}

\author{
Cory J. Lindgren ${ }^{1}$, Rosemary Postey ${ }^{2}$, Ken De $\mathrm{SMeT}^{3}$, Chris Higgs ${ }^{4}$, and Amy B. Thompson ${ }^{5}$ \\ ${ }^{1} 3534$ Rebeck Road, East St. Paul, Manitoba R2E 1C3 Canada \\ 2,5 Manitoba Agriculture, Food and Rural Initiatives, Agricultural Services Complex, 545 University Crescent, Winnipeg, \\ Manitoba R3T 5S6 Canada \\ ${ }^{3}$ Manitoba Conservation, Box 24, 200 Saulteaux Crescent, Winnipeg, Manitoba R3J 3W3 Canada \\ ${ }^{4}$ Prairie Crocus Services, 964 Windermere Avenue, Winnipeg, Manitoba R3T 1A1 Canada
}

Lindgren, Cory J., Rosemary Postey, Ken De Smet, Chris Higgs, and Amy B. Thompson. 2009. West Nile Virus as a cause of death among endangered Eastern Loggerhead Shrikes, Lanius ludovicianus migrans, in West St. Paul, Manitoba. Canadian Field-Naturalist 123(1): 7-11.

In July 2006, three Eastern Loggerhead Shrike (Lanius ludovicianus migrans) nestlings were found dead in a nest in West St. Paul, near Winnipeg, Manitoba. The Eastern Loggerhead Shrike is an endangered form in Canada and populations are in decline. Reverse transcription-polymerase chain reaction and immunohistochemical staining detected West Nile virus in the tissues of the nestlings indicating the cause of death. This is the first confirmed report of West Nile virus in wild populations of Eastern Loggerhead Shrikes in North America. These findings will challenge conservation biologists in their efforts to develop recovery and management plans for the endangered Eastern Loggerhead Shrike, as well as in the implementation of captive rearing programs.

Key Words: West Nile virus, Eastern Loggerhead Shrike, Lanius ludovicianus migrans, endangered species, immunohistochemistry, RT-PCR, flavivirus.

West Nile Virus (Flavivirus: Flaviviridae) was first discovered in North America in New York City in 1999 and has since spread across much of the continent (Lanciotti et al. 1999; Drebot et al. 2003; Bertelsen et al. 2004; Nash et al. 2006). Birds are the principal amplification hosts of West Nile Virus and Culex mosquitoes are recognized as the major vector (Rappole et al. 2000; Lanciotti et al. 2000; Drebot et al. 2003; McLean 2006). North American data revealed that about 48000 birds [predominantly American Crows (Corvus brachyrhynchos) and Blue Jays (Cyanocitta cristata)] belonging to about 300 species have been reported infected with West Nile Virus in the North America alone (McLean 2006). The Eastern Loggerhead Shrike (Lanius ludovicianus migrans) is a subspecies of grassland songbird found in North America. West Nile Virus has previously been found in a population of captive Eastern Loggerhead Shrikes in Ontario, where five Eastern Loggerhead Shrikes died in 2002, at the Toronto Zoo's captive breeding facility (Bertelsen et al. 2004). West Nile Virus was confirmed in all organs examined using immunohistochemistry, and its viral genome was amplified from brain and kidney samples using reverse transcription (RT) - polymerase chain reaction (PCR) (Bertelsen et al. 2004).

The wild Loggerhead Shrike (Lanius ludovicianus) population has experienced persistent declines across its North American range since 1966 (Pruitt 2000*). These declines have been most significant in the range of the Eastern Loggerhead Shrike, a subspecies found in the northeastern and mideastern United States and in eastern Canada (Pruitt 2000*). The Eastern Loggerhead Shrike has been considered endangered in Canada since 1991 and was officially listed as endangered under the federal Species at Risk Act in 2003 (Wildlife Preservation Canada 2005*; Environment Canada 2006*).

In Canada, the Eastern Loggerhead Shrike is extirpated from Quebec as well as the Maritime provinces. Sharp population declines have been observed in remaining pockets of suitable habitat in Ontario and Manitoba (Government of Canada 2008*). In 2004, surveys revealed 36 known breeding pairs in Canada (Wildlife Preservation Canada 2005*). Subsequent surveys revealed further declines in wild populations to 20 pairs in 2005, and to 22 pairs in 2006 (Wildlife Preservation Canada 2005*; Lindgren 2006*). In Manitoba, numbers declined from 11 known breeding pairs in 2000 to five pairs in 2006 (Lindgren 2006*). It has yet to be determined why Loggerhead Shrike populations are in decline, and hence, there is an urgent need to better understand limiting factors that may be contributing to these declines. Although suitable habitat for Eastern Loggerhead Shrikes appears to exist in several areas throughout Manitoba, its population continues to decline.

West Nile Virus was first detected in birds in Manitoba on 15 July 2002 (Preston 2002; Drebot et al. 2003). A literature search found no reports of West Nile Virus infecting Eastern Loggerhead Shrikes in Mani- 
toba or in any other wild populations across its range although diseases were involved in the deaths of at least two captive Eastern Loggerhead Shrikes (Pruitt $\left.2000^{*}\right)$. This paper represents the first report of West Nile Virus causing death in wild Eastern Loggerhead Shrikes providing documentation of a natural West Nile Virus infection in a new susceptible bird species, contributing to the information on the natural history, spatial distribution, epizootiology, and virus-vectorhost relationship of the disease.

\section{Methods}

Since 2000, Eastern Loggerhead Shrike nesting activity in southeastern Manitoba has been monitored in three core breeding areas immediately north and west of Winnipeg where the birds annually return to nest. These core areas are the suburban municipalities of West St. Paul (49 $\left.58^{\prime} \mathrm{N}, 9^{\circ} 4^{\prime} \mathrm{W}\right)$, Rosser (49 $59^{\prime} \mathrm{N}$, $\left.97^{\circ} 26^{\prime} \mathrm{W}\right)$, and Headingly ( $\left.49^{\circ} 52^{\prime} \mathrm{N}, 97^{\circ} 24^{\prime} \mathrm{W}\right)$. Annual surveys for Eastern Loggerhead Shrikes involve searches for returning birds at nesting sites from previous years and in other suitable habitats near the city of Winnipeg. Nests, once located, are followed up through regular nest checks to determine parents, final clutch size, and the number of young that hatch and survive to fledging age.

Three dead nestlings were discovered in their nest during a routine check and a complete necropsy was conducted on all three. Overall findings were very similar in all three cases and were therefore combined into a single case report. Various tissues were collected for analysis in bacteriology and virology. Representative samples of the major organs were also processed for histopathology and stained with hematoxylin and eosin (Bertelsen et al. 2004). Frozen brain, heart, and kidney samples were analyzed for the presence of West Nile Virus ribonucleic acid (RNA) by RT-PCR (Lanciotti et al. 2000; Drebot et al. 2003). In brief, $5 \mathrm{~mm}^{3}$ pieces of frozen tissue were placed in microtubes (safeseal tubes with lid, Sarstedt, St-Leonard, Quebec) containing $1.5 \mathrm{~mL}$ of RLT lysis buffer (RNeasy mini kit, Qiagen, Mississauga, Ontario), 0.1 M 2-mercaptoethanol (Fisher Scientific, Whitby, Ontario), 0.4\% (w/v) sarkosyl detergent (Sigma-Aldrich, Oakville, Ontario) and either one (for brain) or three (for heart and kidney) $1 / 8$ inch stainless steel ball bearings (BC-Bearing, Winnipeg, Manitoba). The microtubes were placed in balanced pairs on chilled 24-place racks (TissueLyser Adapter Set, Qiagen, Mississauga, Ontario) and shaken for 3 minutes at $25 \mathrm{~Hz}$ using a Mixer Mill homogenizer (model 300, Retsch, Newton, Pennsylvania, USA). Ribonucleic acid was extracted from the homogenate, eluted in nuclease-free Tris-EDTA buffer (pH 8.0; Ambion/ Applied Biosystems, Streetsville, Ontario), and stored until used (Lanciotti et al. 2000).

An RT-PCR assay that amplifies a 238 base pair fragment of the non-structural protein 3 region of the West Nile Virus genome was then conducted using the eluted RNA. The assay was performed with a onestep RT-PCR kit (Qiagen, Mississauga, Ontario) using $3 \mu \mathrm{L}$ of RNA and $300 \mathrm{~mm}$ of each primer (i.e., NS3a and NS3d, Drebot, personal communication) in $25 \mu \mathrm{L}$ reaction volumes. This was then overlaid with one drop of molecular biology grade light mineral oil (SigmaAldrich, Oakville, Ontario). Reactions were carried out in a programmable thermal cycler (MJ Research model PTC 100, Bio-Rad Laboratories, Mississauga, Ontario) using a modified "step down" thermocycling program with 57 cycles of amplification (Hecker and Roux 1996). After thermocycling, $3 \mu \mathrm{L}$ of gel loading solution (50\% sucrose, 2 mM EDTA, $0.1 \%$ bromophenol blue, $0.1 \%$ xylene cyanole; $\mathrm{pH} 8.0$ ) was mixed into each reaction, and a $13 \mu \mathrm{L}$ fraction was analyzed by electrophoresis in a composite agarose-acrylamide gel (Visigel, Stratagene, La Jolla, California, USA) containing $0.15 \mu \mathrm{g} / \mathrm{mL}$ ethidium bromide. After electrophoresis, the gels were visualized on a UV transilluminator (Fisher Scientific, Whitby, Ontario) and photographed using a Polaroid gel camera (Fisher Scientific, Whitby, Ontario).

To support the RT-PCR results and confirm that West Nile Virus was present in the actual cells of the tissues, as there were minimal histological lesions, paraffin blocks of brain, heart, and kidney were submitted to the Immunology Laboratory of Prairie Diagnostic Services (Saskatoon, Saskatchewan). Immunohistochemical staining was conducted using a technique adapted for an automated slide stainer (CodeOn Histomatic Stainer, Fisher Scientific, Edmonton, Alberta) (Haines and Chelack 1991), with a 1:1000 and 1:2000 dilution of rabbit anti-West Nile Virus antibody (BioReliance Corp., Rockville, Maryland, USA). Binding of the primary antibody was detected using goat anti-mouse and anti-rabbit immunoglobulins conjugated to peroxidase-labelled polymers (EnVision + Dual Link, Dako Canada Inc., Mississauga, Ontario).

\section{Results}

Surveys during April through July 2006 revealed at least five nesting Eastern Loggerhead Shrike pairs in the core areas near Winnipeg. Only one of these pairs was located in West St. Paul, at a site that been successful every year since 2001 and had produced a successful second clutch in 2003. On 13 May 2006, the West St. Paul nest was observed with a completed clutch of five eggs. Four of the eggs hatched and the young were banded on 6 June 2006. They fledged a few days later and were observed with the adults in various locations throughout the nesting territory for at least the next month. In late June, the pair began to build a second nest in a Siberian Elm (Ulmus pumila) tree about 200 meters from the original nest site. On 4 July 2006, the nest contained a complete clutch of four eggs. By 13 July 2006, three young had hatched. On 20 July 2006, the young had reached ideal banding age (i.e., seven to ten days old) and were banded. 


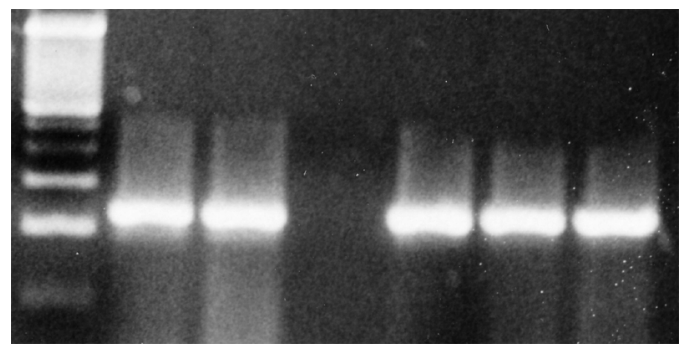

FIGURE 1. Photomicrograph of an ethidium-bromide-stained agarose gel of polymerase chain reaction products obtained with use of a West Nile Virus primer set. From left to right, the far left lane is a 100-base-pair (bp) DNA ladder (invitrogen). The next two lanes identified are amplified DNA from the positive control. The middle lane is a negative control (i.e., no DNA). The next three lanes represent DNA obtained from three Eastern Loggerhead Shrike nestlings. Each test consisted of pooled avian heart, brain, and kidney tissue from an individual nestling.

The approximately two-week old nestlings appeared healthy when observed on 26 July 2006, but were found dead in the nest on 29 July 2006. The dead young appeared undisturbed and there was no evidence that they had struggled. The circumstances surrounding the deaths were considered unusual and the young were immediately collected and frozen for later analysis.

Gross post-mortem findings following necropsy of the nestlings were non-specific, with evidence of dehydration in that the eyes were sunken and the skin was difficult to remove. A few bones, hair, and plant stalks were found in the ventriculus, but otherwise the digestive tract was completely void of contents. The liver and lungs appeared to be congested. No other significant abnormalities were observed and there was no evidence of any trauma.

Analysis in bacteriology and virology revealed no significant bacteriological organisms or intestinal parasites, allowing for the elimination of the possibility of septicaemia. Polymerase chain reaction (PCR) results for brain, kidney, heart, and lung tissue returned negative for both Newcastle Disease and Influenza-A matrix. Histopathology and staining analysis revealed lymphoid depletion and necrosis were evident within scattered follicles of the bursa of one bird and rare blood vessels in the lungs and glomeruli contained fibrin thrombin. No other significant abnormalities were observed. Immunohistochemical staining results were positive for West Nile Virus antigen in all tissues submitted (Figure 1).

\section{Discussion}

With strong West Nile Virus genome amplification and positive staining for West Nile Virus antigen in the bird tissue, along with high Culex tarsalis counts in the region, it was concluded that West Nile Virus was the acute cause of death in all three Eastern Log- gerhead Shrike nestlings. This is the first confirmed report of West Nile Virus killing wild Eastern Loggerhead Shrikes in North America. Our results are significant for conservation biologists, as it has implications for recovery and management plans for the subspecies, and therefore West Nile Virus must be considered as a significant limiting factor for Eastern Loggerhead Shrikes. The breeding behaviour of the Eastern Loggerhead Shrike also makes it more susceptible to the virus. Loggerhead Shrikes aggregate their breeding territories and these aggregations result in the attraction of conspecifics (Cade and Woods 1997). These aggregations of nesting shrikes would make populations particularly vulnerable to disease outbreaks such as the West Nile Virus outbreak in New York City in 1999 where large numbers of dead or dying birds were observed concurrently with clinical reports of human infection (McLean 2006) and dieoffs of captive birds at the Bronx Zoo (Rappole et al. 2000; Steele et al. 2000). Our results also have implications for captive rearing programs. The release of young birds should not occur in areas suspected to have West Nile Virus or areas that have large populations of the C. tarsalis mosquito. Also, careful consideration as to where captive rearing facilities are placed in the environment is needed with respect to potential or historical West Nile Virus zones. Conservation biologists may want to consider setting out mosquito traps to assess mosquito populations prior to releases of captive reared Eastern Loggerhead Shrikes. Further, captive rearing programs should consider vaccination programs prior to release of shrikes into the wild. For example, this technique has been proven effective in the past where the highly endangered California Condor (Gymnogyps californianus) was successfully vaccinated both in captivity and in the wild, stimulating protective immunity in adults, nestlings and newly hatched chicks (Chang et al. 2007).

For the Eastern Loggerhead Shrike, the impacts of West Nile Virus may be more severe as these birds exist in small, isolated populations that are already threatened by habitat loss (Naugle et al. 2004). This has already been shown for the endangered Greater Sage-Grouse (Centrocercus urophasianus), whose population is under similar circumstances, an endangered species in Canada which is susceptible to West Nile Virus (Clark et al. 2006). Fieldwork has indicated that West Nile Virus has resulted in a 25\% decline in survival in Greater Sage-Grouse in Alberta, Wyoming and Montana (Naugle et al. 2004; Walker et al. 2004).

West Nile Virus infection rates are higher in nestlings than in adult birds and nestlings may also be more susceptible to mosquito bites as they are physically incapable of avoiding mosquito attack (Austin et al. 2004). Further, second clutches of young Eastern Loggerhead Shrike may be more susceptible to West Nile Virus in Manitoba as they coincide temporally and spatially with the peak of the C. tarsalis popula- 
tion levels (Figure 2). Mosquito surveillance data indicate that West Nile Virus peaks in southern Manitoba at the end of July and beginning of August, the precise time when the young Eastern Loggerhead Shrike in this case died (Manitoba Health 2006a*). For example, an average high of 83 adult $C$. tarsalis (i.e., the species known to carry West Nile Virus) mosquitoes were caught per trap during the week of 23-29 July 2006 in the Winnipeg area (Manitoba Health 2006b*). Further elevating the risk to the Eastern Loggerhead Shrike, large numbers of $C$. tarsalis mosquitoes have historically been attracted to the West St. Paul area, one of the core breeding areas for the Eastern Loggerhead Shrike. In July 2006 an order was issued under Manitoba's Environment Act to control the mosquitoes in this area as a significant number had become infected with West Nile Virus (Manitoba Health 2006b).

Our results also provide evidence of Eastern Loggerhead Shrike derived mosquito blood meals. Knowledge of vector host preferences is important in understanding West Nile Virus transmission cycles and identifying primary amplifying hosts (Lee et al. 2002; Ngo and Kramer 2003; Molaei and Andredis 2006; Molaei et al. 2006). Polymerase chain reaction assays have been used to identify blood meals of mosquitoes finding feeding preferences for numerous avian species; however, no reports of blood meals derived from Eastern Loggerhead Shrikes (Lee et al. 2002; Ngo and Kramer 2003; Molaei and Andredis 2006; Molaei et al. 2006).

Finally, potential impacts of West Nile Virus on the Manitoba Eastern Loggerhead Shrike are amplified as it is a unique defined population that has adapted to suburban areas. The preference for suburban areas also makes it more susceptible to West Nile Virus as nesting locations tend to be closer to marshes and wetlands. The Manitoba nesting population of Eastern Loggerhead Shrike has traditionally differed from the Ontario population in its preference for suburban, residential breeding habitats. Therefore, the Manitoba population may well represent unique genetic adaptations expressed in their preference for suburban regional environments. Ontario populations, on the other hand, are generally associated with active or idle pasture, grassland, or old field habitats (Chabot et al. 2001; COSEWIC 2004*) and these habitats are being lost due to expanding urbanization and agricultural intensification. As these habitats are lost, the Ontario Eastern Loggerhead Shrike population may also be eventually lost. The Manitoba population then may be better adapted to sustain, and potentially increase, overall population numbers in light of its unique preference for suburban habitats. Acclimating urban shrikes to suburban environments remains a possibility (Cade and Woods 1997). In conclusion, the West Nile Virus presents a new challenge to the survival of the Eastern Loggerhead Shrike in Canada as well as to conservation biologists in species at risk recovery planning.

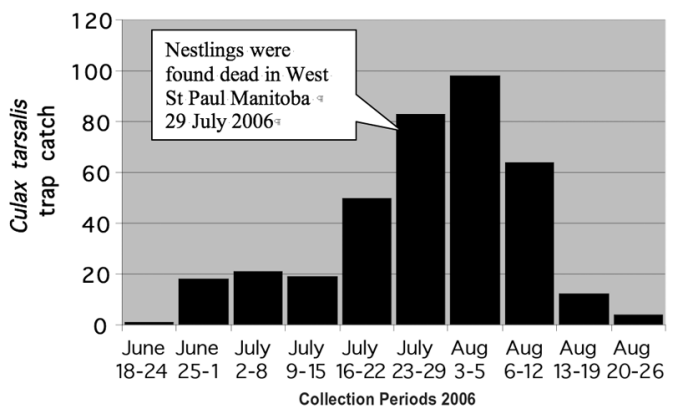

FIGURE 2. Average adult Culex tarsalis trap counts per week for the Winnipeg regional health authority area for 2006. Second clutches produced by Eastern Loggerhead Shrikes may be more susceptible to West Nile Virus as they coincide temporally and spatially with peak $C$. tarsalis population levels in the Winnipeg (Manitoba) area.

\section{Acknowledgments}

We thank the landowners who graciously allowed researchers to enter their properties and monitor the nesting activities of the shrikes; also Terry Whiting (Office of the Chief Veterinarian, Manitoba Agriculture Food and Rural Initiatives, Winnipeg, Manitoba) and Mike Drebot (National Microbiology Laboratory Public Health Agency of Canada, Winnipeg, Manitoba) for reviewing and commenting on earlier drafts of this paper.

\section{Documents Cited (marked $*$ in document)}

COSEWIC 2004. COSEWIC assessment and update report on the Loggerhead Shrike excubitorides subspecies Lanius ludovicianus in Canada. Committee on the Status of Endangered Wildlife in Canada, Ottawa.

Environment Canada. 2006. Recovery strategy for the Eastern Loggerhead Shrike (Lanius ludovicianus migrans) in Canada [Proposed]. Species at Risk Act. Recovery Strategy Series. Environment Canada, Ottawa. 19 pages.

Government of Canada. 2008. Species at Risk Public Registry (cited 2008). Available from http://www.sararegistry. gc.ca.

Lindgren, C. 2006. Eastern Loggerhead Shrike Final Report. Report for the Eastern Manitoba Loggerhead Shrike Recovery Action Group. Winnipeg, Manitoba, Canada.

Manitoba Health. 2006a. West Nile virus update \#8. Available from http://www.gov.mb.ca/chc/press/top/2006/07/ 2006-07-27-03.html.

Manitoba Health. 2006b. Surveillance for West Nile virus in Manitoba. Available from http://www.gov.mb.ca/health/ wnv/stats2006.html.

Pruitt, L. 2000. Loggerhead Shrike Status Assessment. U.S. Fish and Wildlife Service report. 169 pages.

Wildlife Preservation Canada. 2005. Eastern Loggerhead Shrike. Available from http://www.wptc.org/wildlife/shrike. php. 


\section{Literature Cited}

Austin, R., T. Whiting, T., R. Anderson, and M. Drebot. 2004. An outbreak of West Nile virus-associated disease in domestic geese (Anser anser domesticus) upon initial introduction to a geographic region, with evidence of bird to bird transmission. Canadian Veterinarian Journal 45: 117-123.

Bertelsen, M. D., R. Olbert, G. Crawshaw, A. Dibernaro, L. Lindsay, M. Drebot, and I. Barker. 2004. West Nile virus infection in the Eastern Loggerhead Shrike (Lanius ludovicianus migrans): Pathology, epidemiology, and immunization. Journal of Wildlife Diseases 40: 538-542.

Cade, T., and C. Woods. 1997. Changes in distribution and abundance of the Loggerhead Shrike. Conservation Biology 11: 21-31.

Chabot, A., R. Titman, and D. Bird. 2001. Habitat use by loggerhead shrikes in Ontario and Quebec. Canadian Journal of Zoology 79: 916-925.

Chang, G., B. Davis, C. Stringfield, and C. Lutz. 2007. Prospective immunization of the endangered California condors (Gymnogyps californianus) protects this species from the lethal West Nile Virus infection. Vaccine 25: 2325-2330.

Clark, L., J. Hall, R. McLean, M. Dunbar, K. Klenk, R. Bowen, and C. Smeraski. 2006. Susceptibility of greater sage-grouse to experimental infection with West Nile Virus. Journal of Wildlife Disease 42: 14-22.

Drebot, M., A. Lindsay, R. Barker, I. Fearon, M. Hunter, F. Sockett, and H. Artsob. 2003. West Nile virus surveillance and diagnosis: A Canadian perspective. Canadian Journal of Infectious Disease 14: 105-114.

Haines, D., and B. Chelack. 1991. Technical considerations for developing enzyme immunohistochemical staining procedures on formalin-fixed paraffin-embedded tissues for diagnostic pathology. Journal of Veterinary Diagnostic Investigation 3: 101-112.

Hecker, K., and K. Roux. 1996. High and low annealing temperatures increase both specificity and yield in touchdown and stepdown PCR. BioTechniques 20: 478-485.

Lanciotti, R., A. Kerst, S. Nasci, M. Godsey, C. Mitchell, H. Savage, N. Komar, N. Panella, K. Vople, B. Davis, and J. Roehrig. 2000. Rapid detection of West Nile virus from human clinical specimens, field-collected mosquitoes, and avian samples by a TaqMan reverse transcriptase-PCR assay. Journal of Clinical Microbiology 38: 4066-4071.

Lanciotti, R., J. Roehrig, V. Deubel, M. Smith, K. Parker, B. Steele, K. Crise, M. Volpe, B. Crabtree, J. Scherret, R. Hall, J. Mackenzie, C. Cropp, B. Panigrahy, E. Ostlund, B. Schmitt, M. Malkinson, C. Banet, J. Weissman, N. Komar, H. Savage, W. Stone, T. McNamara, and D. Gubler. 1999. Origin of the West Nile virus responsible for an outbreak of encephalitis in the northeastern United States. Science 286: 2333-2337.
Lee, J., H. Hassan, G. Cupp, T. Higazi, C. Mitchell, M. Godsey, and T. Unnasch. 2002. Identification of mosquito avian-derived blood meals by polymerase chain reaction-heteroduplex analysis. American Journal of Tropical Medicine and Hygiene 66: 599-604.

McLean, R. 2006. West Nile virus in North American birds. Ornithological Monographs 60: 44-64.

Molaei, G., and T. Andredis. 2006. Identification of avian and mammalian-derived bloodmeals in Aedes vexans and Culiseta melanura (Diptera: Culicidae) and its implications for West Nile virus transmission in Connecticut, U.S.A. Journal of Medical Entomology 43: 1088-1093.

Molaei, G., T. Andredis, P. Armstrong, J. Anderson, and C. Vossbrinck. 2006. Host feeding patterns of Culex mosquitoes and West Nile virus transmission, Northeastern United States. Emerging Infectious Diseases 12: 468474.

Nash, D., F. Mostashari, A. Fine, J. Miller, D. O'Leary, K. Murray, A. Huang, A. Rosenberg, A. Greenberg, M. Sherman, S. Wong, and M. Layton. 2006. The outbreak of West Nile virus infection in the New York City area in 1999. The New England Journal of Medicine 344: 1807-1814

Naugle, D., C. Aldrige, B. Walker, T. Cornish, B. Moynahan, M. Holloran, K. Brown, G. Johnson, E. Shcmidtmann, R. Mayer, C. Kato, M. Matchett, T. Christainsen, W. Cook, T. Creekmore, R. Falise, E. Rines, and M. Boyce. 2004. West Nile virus: pending crisis for greater sagegrouse. Ecology Letters 7: 704-713.

Ngo, K., and L. Kramer. 2003. Identification of mosquito bloodmeals using polymerase chain reaction (PCR) with order-specific primers. Journal of Medical Entomology 40: 215-222.

Preston, A. 2002. West Nile fever update. Israel Journal of Veterinary Medicine 57: 169-170.

Rappole, J., S. Derrickson, and Z. Hubakek. 2000. Migratory birds and spread of West Nile virus in the Western Hemisphere. Emerging Infectious Diseases 6: 319-328.

Steele, K., M. Linn, R. Schoepp, N. Komar, T. Geisbert, R. Manduca, P. Calle, B. Raphael, T. Clippinger, T. Larsen, J. Smith, R. Lanciotti, N. Panella, and T. McNamara. 2000. Pathology of fatal West Nile virus infections in native an exotic birds during the 1999 outbreak in New York City, New York. Veterinary Pathology 37: 208-224.

Walker, B., D. Naugle, K. Doherty, and T. Cornish. 2004. From the Field: Outbreak of West Nile virus in great sagegrouse and guidelines for monitoring, handling, and submitting dead birds. Wildlife Society Bulletin 32: 10001006.

Received 4 November 2008

Accepted 15 June 2009 